\title{
The Linkage between Decentralization and Governance: Bring Politics Back In?
}

\author{
Himawan Bayu Patriadi, PhD \\ Faculty of Social and Political Sciences \\ University of Jember - Jember, Indonesia \\ Email: hbpatriadi@unej.ac.id
}

\begin{abstract}
There has been a general assumption that the adoption of decentralization would facilate the improvement of governance quality. Based on an empirical study of Indonesia case, however, it is argued that such a kind of assumption is not always the case. Any good governance is hard to achieve because the complexity of its surrounding context, particularly the political ones. Given this, it can thus be suggested that in analysing any administrative phenomenon it is not neceessary to be exclusively reliant on the Wilsonian approach which separates public administration from politics. In order to have a functional analyses, particularly dealing with phenomenon in developing countries, it might be better to employ a wider perspective involving the usage of other discipline's approach, including politics.
\end{abstract}

Keywords: decentralization; governance; politics

\section{INTRODUCTION}

Do public organs stay in a vacuum? Does decentralization always have positive correlation with good governance ? These two provocative questions come up in my mind after for sometime exploring Indonesia case study and observing empirical phenomenon dealing with some public services. They then struck me even further after knowing that some suggesting answers for those mostly are merely normative theoretical propositions. Bearing this in mind, this paper tries to explore and critically discuss about the issue. After shortly reviewing the development of public administration approaches, it then explores some empirical facts as the departing point for further discussion. Finally, the paper will be concluded by some insights on the issue to refining any academic or theoretical relevance.

\section{DEMOCRATIC GOVERNANCE: SOME THEORETICAL PROPOSITIONS}

Until quite recently, good governance has become one of the development focus, particularly in developing countries. Part of the agenda is how to improve public bureaucracy performance. Some imperative concepts have even been suggested. One of them is the installation of democratic governance. As a concept, governance has both academically and practically been widely accommodated. While some see it as the new public management, others also perceive governance as a 'reinvented' form of government which is better managed to achieving greater efficiency in the production of public services". ${ }^{1}$ Having this, optimism seems to continually endure hoping that adoption of 'good' governance, at least normatively, would improve the performance of public organs, particularly bureaucracy.

As many assumed, devolution of power from central to local authorities, commonly called it as the project of decentralization, is good effort of establishing 'good' governance. It has even theoretically been argued that such a devolution of the centralized power would in turn be able to make goverment more efficient, responsible, and accountable; so it hopefully could provide better delivery of public services. $^{2}$ In this sense, the installation of local democratic governanve would be conducive for materializing those criteria assuming that democratically elected local authorities are better in managing delivery of public services. One of the reasons was raised by two prominent public administration theorists, Shabbir Cheema and Dennis Rondinelli, who argue that, compared to their undemocratically elected upper level counterparts, democratically elected local authorities are more knowledgeable on local aspirations and consequently they would be more responsive to local demands. ${ }^{3}$ Another reason is that any democratic governance would also encourage effectiveness and efficiency of governing because democratically-elected local govermnent imperatively should be politically accountable to their constituent. In other words, under democratic governance local government unavoidably should consider the aspirations of stake holders involved . Hence, Saito is unquestionably right when he defined governance as "a process and outcome of consultative interaction between different constituent members including public, private and civil organizations in order to resolve common political economic and social issues". 4

All arguments above has laid a strong foundation for installing democratic governnance. While many believe that

\footnotetext{
${ }^{1}$ Gerry Stoker, "Governance as Theory: Five Propositions”, ISSJ, Vol. 155, 1998, pp.17-18.

${ }^{2}$ Merilee S. Grindle, Going Local: Decentralization, Democratization and the Promise of Good Governance, Princeton University Press, Princeton, 2007. p. 167.

${ }^{3}$ John Martinussen, Society, State \& Market: A Guide to Competing Theories of Development, Zed Book Ltd., New York, 1997, p. 214.

${ }^{4}$ Fumihiko Saito, "Decentralization and Local Governance: Introduction and Overview", in Fumihiko Saito, ed., Foundations for Local Governance: Decentralization in Comparative Perspective, Physica-Verlag, Heidelberg, 2008 , p.6.
} 
decentralization would have good impacts on governance, few empirical studies have however been done to investigate the linkage between the two. As such, any prospective of governing, particullarly that at the local level, needs to be confirmed: How far does it fit with what happened in developing countries? The next section below, empirically will provide a general empirical picture of governance under the installed decentralization.

\section{EMPIRICAL TESTING OF THEORY: THE INDONESIA CASE}

For most developing countries, including Indonesia, both decentralization and 'good' governance for the most part are 'alien' concepts. One of the reasons is that the two are basically the 'imported' things because of various reasons whether positive or negative. They used to be installed or accommodated mostly due to being forcefully imposed into the long established socio-cultural and political traditions. In this respect, Kohli cpgently predicted that there would be 'disquieting' situation for at least certain period once the imported things being transplanted into the traditions..$^{5}$ As such, challenges are always available and needs to be investigated and solved.

It was been estimated that four fifth of the countries on the world has done decentralization projects. ${ }^{6}$ Dealing with this fact, interestingly, many are of the same mind that the adopted project was mainly driven by the motive of improving th nature and quality of governance. ${ }^{7}$ Nevertheless, while analyses of socio-cultural constrains are enormous, study of how political aspects characterize the nature of the relationship between decentralization and governance seems to be still relatively limited.

Indonesia is one of the countries in which decentralization has been adopted for more than one decade following the installation of democractic governance in 1998. For the initial period of the implementation, public assumed the adopted decentralization needed adaptation of bureaucracy mindset and behaviour that fit with the spirit of decentralization. Such an perception was dominant having the fact that under the centralized system for more than three decades, public bureaucracy used to be heavy implementors rather than decisive policy makers. It is widely acknowledged that in order to effectively managing decentralization at the local level the main required capacity was autonomous creativy. I myself was even also personally involved in several internships of converting local-level bureaucracry's mindset

\footnotetext{
5 Atul Kohli, "On Sources of Social and Political Conflicts in Follower Democracies" in Axel Hedenius ed., Democracy's Victory and Crisis, Cambridge University Press, Cambridge, 1997, pp.71-80.

6 J. Manor, The Political Economy of Decentralization, The World Bank, Washington DC, 1999.

${ }^{7}$ Jean-Paul Faguet, "Decentralization and Governance”, EOPP paper/2011/27, downloaded from

http://sticerd.1se.ac.uk/_new/publications/series.asp?prog=EOPP[6 May 2016]
}

and behaviour. The main agenda thus simply focussed on socio-cultural aspects.

Nevertheless, after observing the implemented decentralization intensively for sometime, in particular how previous public optimism did not meet with it, it became clear that the problem of decentralization not only limited on uncondusive socio-culture but also unsuitable political aspects. In it, ironically, a better quality of governance cannot optimally be achieved because of the adoption of democratic government. In this sense, poor democractic practices indeed mattered on the decentralization.

Based on on the case of Indonesia, I elsewhere have wrote about the impacts of political development on the implemented decentralization. ${ }^{8}$ As written, Indonesia has adopted a comprehensive decentralization involving administrative, financial and political aspects since the implementation of Government Act no. 22/1999 and 25/1999 as the underpinning of local autonomy followed by the revised Government Act no. 25/2004 and 34/2004 as the foundations of the central-local fiscal distribution. Dealing with the first two aspects, the progress so far have relatively met with the expectations. Although at the beginning the power transference from the central made many local bureucrats hard to handle, because of regular trainings coupled with experienced-based learning their capabilities have then increased overtime. In line with the positive trend of human development, financial aspect also showed an impressive result. In general, local expenditures has steadily been boosted by the financial decentralization. Data from 1997 to 2007 illustrated that the local expenditures had almost quadruppled nationwide, from US\$ 40 billion to US\$ 140 billion. ${ }^{9}$

Yet, as long as related to the political aspect, the early hope seems hard to fulfill. The adoption of decentralization together with local democracy is not a panacea, and to certain extend has made negative complexity in enhancing the quality of governance. As has also been elaborated on the article, based on interviews with credible sources, the installation of local democracy has instilled rampant money politics, bossism and clientilism. ${ }^{10}$ In it, it has been shown how wide-ranging money politics has encouraged high-cost politics, in which this phenomenon in turn encouraged the nature of governance getting worse. In line with this, bossism followed by clientilism also made coordination of implementors units within local bureaucracy hard to manage. This is partly because the formal line of command to some extent was disfunctional due to the intervention from the elected political leader's informal supporters.

\footnotetext{
8 Himawan Bayu Patriadi, "Democracy, Decentralization and Governance Reconsidered: The Case of Indonesia", a paper presented in Thailand international conference on "Public Management and Public Affairs: Challenges and Prospects in ASEAN and Beyond", The Public Administration Association of Thailand, Bangkok, 30-31 August 2012.

${ }^{9}$ As reported in Australian Financial Review, 14 February 2007

${ }^{10}$ See Patriadi, op.cit.
} 
Until quite recently, the above occurrences to great extent seemingly continued to endure. My further research once again confirms them. The nature of bossism and clientelism continued to exist curtailing the performance of local public bureaucracy. A credible source within bureaucracy described the situation as follows:

\begin{abstract}
Uninterupted [political] regulation makes unchanging situation. The incident repeated, the practice of local democracy often put us as implementors in uneasy situation. Under the line of command scheme, we are surely Bupati's [District Head] formal staffs. However, not rare the intervention of the Bupati's informal political advocates into projects implementation was difficult to resist, so they often disturbed us in managing certain projects. Such a condition had placed local bureaucrats in a dilemma. If using professional criteria we are of course the appropriate ones, but we are also aware that they are the Bupati's men. Therefore, especially for me, under such situation it is better to be 'prudent' by accomodating them in the projects though it means to downgrade effectiveness and efficiency. ${ }^{11}$
\end{abstract}

In addition, the persistence of money politics practices also further contaminate the execution of public policy. Having such high cost politics, particularly during the local election period, continued to forcefully distort public policy. Before the election day came, not rare incumbent leaders manipulated policy in order to get public sympathy. In this respect, the policy being executed was more reliant on partisan calculation rather than objective consideration. Another source told me like this:

\begin{abstract}
It has become public secret that any incumbent local leaders used to have a tendency using various ways to maintain their political positions. As political cost is so high, they used to utilize any policy to get popular support particularly done upon the time when the election day was approaching, such as 'instantly' financial allocation to pay for some physical projects at villages. At glance, such a kind of political strategy seems to benefit people, but in terms of policy it was more political heavy-driven policy rather than being made based on an objective need-asessment. ${ }^{12}$
\end{abstract}

The two interviews above reveal another dimension of the decentralization complexity. It clearly shows how the good mission of decentralization to enhance the quality of governance is really problematic. Greater effective, efficient responsible and accountable government is still far from being materilialized due to the fact that underlying process of local politics to be more coloured by short term policy that based on material calculation rather than long term policy which reliant on ideas-oriented transaction. What is interesting to be noted here is that the main constrain of establishing good governance is not the character and capacity of public

\footnotetext{
${ }^{11}$ Interview, June 2014.

${ }^{12}$ Interview, November 2015
}

bureaucracy and its related regulations, but the context that vigorously conditions the administration organ.

\section{CONCLUDING REMARKS: RECONSIDERING THE APPROACH}

The emprical exploration above convincingly encourages us to question the general assumption of perceiving decentralization has positive correlation with establishing 'good' governance. Some critical questions can be thus raised here are: how does public management deal with the existing problem above? and, in a wider context, how the approach of public administration should be?

Tracing back the development of Public Administration, one of the long-lasting controversies is the contention of its approaches which is rooted in the different goals of the study of administration. First, as suggested by Woodrow Wilson and Frank J. Goodnow, is that which is based on progressive tradition. This approach tends to be pragmatic by stressing the importance of using science to establish government efficiency. ${ }^{13}$ In other words, this Wilsonian approach presummes that administrators could, or even should, produce 'a set of tools that could be used for any public purpose'. ${ }^{14}$ In order to having this, public administration should therefore be separated from politics. Second, is the approach which wants public administration to have explanatory purpose. In this respect, it hopefully could explain 'the role administration plays in society' with the goal of 'understanding the administrative process so that its functions can be improved'. ${ }^{15}$ The different approaches of course has encouraged an intensive debate within the discipline.

How should we take a position against the debate? The two contending approaches, I argue, should not necessarily be seen as conflicting each other. Referring to the empirical case above, lesson can be learnt is that the administrative phenomenon or problem is unquestionably multifaceted. To be sure, the presumption saying that the quality of governance can be simply achieved through the adoption of decentralization is hard to materialize due to many aspects involved. Democratic governance could indeed not work well because of being conditioned by various political aspects. Bear all these in mind, it can once again be argued that in order to analysing any administrative phenomenon we might need a wider perspective. If necessary, we can do that by borrowing some concepts from other disciplines. In a nutshell, an interdisciplinary approach might be useful to use given the complex context that shapes administrative phenomenon, particularly those which is available in developing countries.

\footnotetext{
13 As quoted in Donald F. Kettl, "Public Administration: The State of The Field", in Ada F. Finifter, ed., Political Science: The State of the Discipline II American Political Science Association, Washington DC, 1993, pp. 407-430. ${ }^{14} \mathrm{Ibid}$.

${ }^{15}$ Ibid.
} 
So, for further contemplation, a central question can be suggested here: how can we solve the administrative problem without understanding the context? To be aware of this, in order to get any functional analyses it might be reasonable to reconcile the two existing approaches to become complementary each other.

\section{REFERENCES}

[1] Australian Financial Review, 14 February 2007

[2] J.P. Faguet, "Decentralization and Governance", EOPP paper/2011/27, http://sticerd.lse.ac.uk/ new/publications/series.asp?prog=EOPP, [6 May 2016]

[3] M.S. Grindle, Going Local: Decentralization, Democratization and the Promise of Good Governance, Princeton University Press, Princeton, 2007.

[4] D.F. Kettl, "Public Administration: The State of The Field", in Ada F. Finifter, ed., Political Science: The State of the Discipline II, American Political Science Association, Washington DC, 1993, pp. 407-430.

[5] A. Kohli, "On Souces of Social and Political Conflicts in Follower Democracies" in Axel Hedenius ed., Democracy's Victory and Crisis, Cambridge University Press, Cambridge, 1997, pp.71-80.

[6] J. Manor, The Political Economy of Decentralization, The World Bank, Washington DC, 1999.

[7] J. Martinussen, Society, State \& Market: A Guide to Competing Theories of Development, Zed Book Ltd., New York, 1997.

[8] H.B. Patriadi, "Democracy, Decentralization and Governance Reconsidered: The Case of Indonesia", a paper presented in Thailand international conference on "Public Management and Public Affairs: Challenges and Prospects in ASEAN and Beyond", The Public Administration Association of Thailand, Bangkok, 30-31 August 2012. Unpublished.

[9] F. Saito, "Decentralization and Local Governance: Introduction and Overview", in Fumihiko Saito, ed., Foundations for Local Governance: Decentralization in Comparative Perspective, Physica-Verlag, Heidelberg, 2008, pp.1-24.

[10] G. Stoker, "Governance as Theory: Five Propositions", ISSJ, Vol. 155, 1998, pp.17-18. 